\title{
Testing of the Adhesion of Herpes Simplex Virus on Textile Substrates and Its Inactivation by Household Laundry Processes
}

\author{
Anja Gerhardts¹, Dirk Bockmühl², Andrea Kyas³, Anja Hofmann4, Mirko Weide5, Ingrid Rapp4, \\ Dirk Höfer ${ }^{1}$
}

${ }^{1}$ William-Küster-Institut for Hygiene, Environment \& Medicine, Hohenstein Institute for Textilinnovation gGmbH, Boennigheim, Germany

${ }^{2}$ Rhine-Waal University of Applied Sciences, Hygiene and Microbiology, Kleve, Germany

${ }^{3}$ Henkel AG \& Co. KGaA, Corporate Scientific Services, Duesseldorf, Germany

${ }^{4}$ Labor Dr. Merk \& Kollegen GmbH, Ochsenhausen, Germany

${ }^{5}$ Henkel AG \& Co. KGaA, International R\&D Laundry \& Home Care, Duesseldorf, Germany

Email:a.gerhardts@hohenstein.de

How to cite this paper: Gerhardts, A., Bockmühl, D., Kyas, A., Hofmann, A., Weide, M., Rapp, I. and Höfer, D. (2016) Testing of the Adhesion of Herpes Simplex Virus on Textile Substrates and Its Inactivation by Household Laundry Processes. Journal of Biosciences and Medicines, 4, 111-125.

http://dx.doi.org/10.4236/jbm.2016.412015

Received: October 28, 2016

Accepted: December 11, 2016

Published: December 14, 2016

Copyright $\odot 2016$ by authors and Scientific Research Publishing Inc. This work is licensed under the Creative Commons Attribution International License (CC BY 4.0).

http://creativecommons.org/licenses/by/4.0/

(c) (i) Open Access

\begin{abstract}
Viral infections like Herpes simplex increasingly pose a serious threat to European health care systems and welfare of the population. Indirect transmission routes of infections via inanimate surfaces are often underestimated. In this study, we investigated the adhesion and persistence of Herpes simplex virus on cotton fabrics as well as its inactivation by domestic laundry. Virus adhesion to textile fibers was distinct, because viral DNA was detectable on fabrics for at least 48 hours after contamination as well as after home laundry. Particles remained infectious for several hours at room temperature and partially for 48 hours at $2^{\circ} \mathrm{C}-8^{\circ} \mathrm{C}$. Nevertheless, domestic laundry was able to inactivate virus particles given that detergents were adequately used. This confirmed that standard household laundry processes, as established in Europe, are a suitable tool to reduce infectious Herpes virus particles from textiles, thereby supporting the prevention of infections circulating in the household and community.
\end{abstract}

\section{Keywords}

Home Laundry, Herpes Simplex, Disinfectant Laundry Processes, Inactivation of Viruses

\section{Introduction}

Herpes simplex virus type 1 and type 2 together with varicella-zoster virus belong to the 
group of Alphaherpesvirinae. Epidemiologically, herpes simplex viruses are distributed worldwide and are among the most common pathogens. The overall seroprevalence of HSV-1 in Europe is about $80 \%$ and nearly $20 \%$ for HSV-2 [1] [2] [3] [4]. Herpes viruses are usually transmitted via droplet infection from throat secretions, as well as by contamination with the vesicle fluid from skin lesions and from the typical mucosal lesions of the oral-facial area (blisters) and genital organs [5].

The most known route of infection for HSV-1 is direct, i.e. through contact with herpes blisters or through saliva. In general, HSV-1 is transmitted in this way already in early childhood by parents, so that in Germany about half of the children are seropositive before entering puberty [2] [6]. A second smaller postpubertal phase of infestation begins with the establishment of intimate contacts [7]. Nevertheless, herpes simplex virus can not only be spread from persons displaying acute symptoms, but also from asymptomatic ones [8]. Actually, infections transmitted by asymptomatic persons today are considered to be the main route [9] [10].

Infectious viral diseases arising in the home environment or community, increasingly pose a serious threat to European health care systems and welfare of the population [11] [12]. Therefore, to successfully contribute to break chains of infection, also indirect transmission routes have to be revealed and investigated. As a particularly sensitive method for the detection of herpes viruses in molecular biology, the polymerase chain reaction (PCR) is used, e.g. to study issues such as virus excretion and the associated risk of transmission [12].

Textile fabrics play a role in the spread of viral diseases that must not to be underestimated [13] [14]. Although several studies showed examples for the indirect transmission of infections via fabrics or inanimate surfaces as summarized earlier [14], there is a lack of awareness for this transmission route in society. Even many hygienists still neglect to advice stricter preventive measures like the daily change of clothes or the use of antimicrobial active surfaces. The indirect route of infection with herpes simplex, i.e. the transmission of virus via hands, lips or saliva first to clothing, towels or other textiles, and forward to non-infected persons, has not been investigated thoroughly so far. Transfer of the herpes pathogen may occur via hand contact from infected blisters content, e.g. when scratched, to inanimate surfaces such as consumer goods and textiles. Mahl and Sadler (1975) were the first to show a possible role of inanimate, hard surfaces in the transmission of herpes virus. They found that herpes simplex virus can survive on glass, ceramic or stainless steel surfaces for at least 8 weeks at room temperature [15]. Also a study on the survival of HSV on plastic-coated benches and seats in spa facilities showed significant amounts of herpes simplex virus after 4.5 hours on plastic surfaces in humid atmosphere, suggesting that fomites may play a role in routes of HSV transmission [16]. In a hospital study about the stability of HSV on environmental surfaces, Turner et al. (1982) showed that herpes virus particles freshly isolated from patients can survive more than two hours on the skin, three hours on clothing and four hours on plastic surfaces, which represents a risk for infection transmission.

Further data on the persistence or inactivation of herpes viruses on textiles are lack- 
ing. Basically, however, it was shown for polio and vaccinia viruses that clothing and household textiles are also able to transfer viruses and other infectious agents [17] [18]. Especially on cotton and wool fibers, the persistence time of polio and vaccinia viruses is high enough to be re-transmitted to objects or people [19].

Against this backdrop, we investigated the question of persistence of the herpes virus in the community. So, we examined HSV DNA on textiles by using fresh isolates from herpes blisters in a practical approach. The polymerase chain reaction was applied to gain an assessment of virus adhesion on textiles during laundry. A disadvantage of this method is that inactivated particles cannot be distinguished from infectious virus. For the verification of infectious virus persistence, we used the HSV-1 laboratory strain hv342. Based on our data, we then wanted to clarify whether specific household laundry processes are able to sanitize textiles contaminated with herpes to avoid potential risks of virus infection among the population by using common established procedures.

\section{Material and Methods}

\subsection{Sampling of Herpes Simplex Virus (HSV)}

Virus-containing swab samples were obtained from lesions on the lips of affected persons with sterile disposable swabs and refrigerated until further processing. The swabs were completely moistened with nuclease-free water and given to an insert for reaction tubes, which was placed in a $1.5 \mathrm{ml}$ reaction vessel. Viruses were eluted from the swabs by centrifugation for $10 \mathrm{~min}$ at $1500 \times \mathrm{g}$ and $4^{\circ} \mathrm{C}$. Virus suspensions of six swab samples were pooled.

\subsection{Specific Detection of HSV via Polymerase Chain Reaction (PCR)}

For amplification of herpes simplex virus DNA, the gene of DNA polymerase was selected as template. PCR primers HSV_pol_fwd (5'-GTGTTCGACTTTGCCAGCCT-3') and HSV_pol_rev (5'-GTCCGTGTCCCCGTAGATGA-3') were modified according to Johnson et al. (2000). Reaction mixtures were prepared in $0.5 \mathrm{ml}$ reaction vessels with 1 $4 \mu \mathrm{l}$ template DNA, $10 \times$ DreamTaq Buffer, $0.4 \mu \mathrm{ldNTPs}(10 \mathrm{mM}), 0.5 \mu \mathrm{l}$ of each primer HSV_pol_fwd and HSV_pol_rev $(10 \mu \mathrm{M}), 0.5 \mathrm{U}$ DreamTaq DNA polymerase (MBI Fermentas, St. Leon-Rot, Germany) and nuclease-free water in a total volume of $20 \mu \mathrm{l}$. PCR reactions were performed in an Eppendorf Mastercycler gradient. The cycling parameters were as follows: pre-incubation for $3 \mathrm{~min}$ at $95^{\circ} \mathrm{C}$ followed by 20 cycles of denaturation for $30 \mathrm{sec}$ at $95^{\circ} \mathrm{C}$, annealing for $30 \mathrm{sec}$ at $59^{\circ} \mathrm{C}$ with a temperature decrement of $-0.2^{\circ} \mathrm{C}$ per cycle and extension for $45 \mathrm{sec}$ at $72^{\circ} \mathrm{C}$. This was followed by 20 cycles of denaturation for $30 \mathrm{sec}$ at $95^{\circ} \mathrm{C}$, annealing for $30 \mathrm{sec}$ at $55^{\circ} \mathrm{C}$ and extension for $45 \mathrm{sec}$ at $72^{\circ} \mathrm{C}$ and a final extension for $7 \mathrm{~min}$ at $72^{\circ} \mathrm{C}$. Reaction products were visualized by gel electrophoresis and ethidium bromide staining in a $1.5 \%$ agarose gel and documented using the GelDoc XR + system (Bio-Rad, Munich, Germany).

\subsection{Identification of Virus Type by Restriction Enzyme Digestion}

A 522 bp fragment was amplified by PCR from the pooled virus suspensions. PCR 
products were digested with the restriction endonucleases BamHI and Bsh1236I (equivalent to $B s t \mathrm{UI}$ ) in separate amplifications. The enzyme BamHI has no restriction sites in the HSV-1 sequence, but in the fragment from HSV-2. Bsh1236I recognizes multiple restrictions sites in the fragments of HSV type 1 and 2 ( 8 or 12, respectively). Therefore HSV-1 and HSV-2 can be differentiated after electrophoretic separation of digested PCR products according to their restriction pattern [20].

\subsection{Determination of the Adhesion of HSV-1 on Textiles}

UV-sterilized textile swatches, approximately $1 \mathrm{~cm}^{2}$ in size, from standard cotton fabric according to DIN 53,919, were inoculated with $10 \mu$ of pooled HSV-1 suspension each. The contaminated cotton swatches were transferred to reaction vessels at different time points after inoculation (after $1 \mathrm{~min}, 30 \mathrm{~min}, 1 \mathrm{~h}, 2,4,6,8,24$ and $48 \mathrm{~h}$ ) and the virus particles were inactivated at $95^{\circ} \mathrm{C}$ for $5 \mathrm{~min}$. For laundry experiments, contaminated swatches were knotted into mull sleeves, placed in a laundry bag and inserted into a standard household laundry process at $40^{\circ} \mathrm{C}$ in a standard household washing machine (Miele Softtronic W1734) with phosphate-free ECE reference detergent (according to DIN EN ISO 6330) and $3.5 \mathrm{~kg}$ of ballast load. Subsequently, all swatches were eluted by centrifugation $\left(4 \mathrm{~min}\right.$ at $11,000 \times \mathrm{g}$ and $\left.4^{\circ} \mathrm{C}\right)$ with $20 \mu \mathrm{l} 1 \times \mathrm{TE}(10 \mathrm{mM}$ Tris, $1 \mathrm{mM}$ EDTA, pH 8). As a control, cotton swatches inoculated with nuclease-free water were incubated and eluted in the same way. For specific detection of virus, $4 \mu \mathrm{l}$ of each eluate was used for PCR as described above.

\subsection{Determination of the Persistence of Infectious Particles}

Sterile cotton swatches, approximately $2 \mathrm{~cm}^{2}$ in size, were inoculated with a mixture of $90 \mu \mathrm{l}$ virus suspension (HSV-1 hv342) and $10 \mu \mathrm{l}$ soil load (bovine serum albumin and sheep erythrocyte suspension according to EN 14,476). The cotton swatches were allowed to dry under laminar flow conditions for 5 minutes, then transferred to sterile petri dishes and were incubated at room temperature $\left(20^{\circ} \mathrm{C}-25^{\circ} \mathrm{C}\right)$ or at $2^{\circ} \mathrm{C}-8^{\circ} \mathrm{C}$, respectively. At different time points $(0.5 \mathrm{~h}, 1 \mathrm{~h}, 2 \mathrm{~h}, 4 \mathrm{~h}, 6 \mathrm{~h}, 8 \mathrm{~h}, 24 \mathrm{~h}, 48 \mathrm{~h}) 1 \mathrm{ml}$ icecold medium (Dulbecco's Modified Eagle's Medium (DMEM), Sigma-Aldrich Chemie $\mathrm{GmbH}$, Taufkirchen, Germany with added antibiotics and L-glutamine) was given to an individualized swatch in a plastic container filled with glass beads and vortexed for 2 $\times 30$ seconds. The suspension was serially diluted and pipetted to Vero cells (ECACC $84,113,001$, African Green Monkey kidney) in a 96 well microtiter plate. The cytopathogenic effect (CPE) was analyzed after 7 days of incubation at $37^{\circ} \mathrm{C} \pm 2{ }^{\circ} \mathrm{C}$ and $5 \%$ $\mathrm{CO}_{2}$ so as to give the virus enough time to proliferate. Two cotton swatches were analyzed per time point to achieve two independent titration results.

For the negative control or cytotoxicity control, the cotton swatches were inoculated with $90 \mu \mathrm{l}$ water of standardized hardness plus $10 \mu \mathrm{l}$ soil load instead of $90 \mu \mathrm{l}$ virus suspension. Those swatches were incubated for 48 hours and analyzed as described above. An interference control was performed the same way as the negative control; after incubation and elution, the obtained suspension and a control fluid, mostly PBS, were 
given to Vero cells for 1 hour. After this incubation time, the fluid was removed and a serial virus dilution was given to the cells to examine that the cells are not negatively influenced by the treatment with cotton derived substances, so that the cells are still susceptible for virus infection. The difference between the titer of the treated and the untreated cells shall not exceed $0.5 \log _{10}$.

As positive virus control, freshly thawed virus aliquot plus soil load was given to cotton swatches and immediately vortexed after 5 minutes of drying with $1 \mathrm{ml}$ DMEM; this was used at specific time points in order to exclude processing errors. Additionally, a suspension control was performed without the use of cotton swatches to examine the effect of the cotton surface face to face with the virus respectively the behavior of cotton concerning the virus recovery. Therefore $90 \mu \mathrm{l}$ virus suspension plus $10 \mu \mathrm{l}$ soil load was mixed with $900 \mu \mathrm{l}$ medium and the serial dilution was pipetted to Vero cells.

The virus titers were determined using the final dilution method. The calculation of virus reduction at different time points was calculated with the mean titer of the duplicate virus control at $\mathrm{T}_{0}$ and the single titer values of swatches achieved in the same experiment. Afterwards, mean values are calculated from all swatches of two independent experiments.

\subsection{Determination of the Virus-Inactivating Efficacy of Laundry Processes}

The virus-inactivating effect of common household laundry processes was assessed based on the reduction of the HSV-1 titer on contaminated germ carriers. Therefore, Herpes virus (HSV-1 hv342) was cultured on Vero B4 cells (DSMZ ACC 33; African Green Monkey kidney) using DMEM (Dulbecco's Modified Eagle Medium, Biochrom, Berlin, Germany) supplemented with 5\% fetal calf serum (Biochrom, Berlin). Virus suspensions were obtained in accordance with the guideline of the German Association for the Control of Virus Diseases and the Robert Koch Institute for testing of chemical disinfectants effective against viruses used in human medicine [21]; the virus titers were determined using the final dilution method. The final dilution method is based on the infectivity of the actual dilution of test material. Therefore, several dilutions are done in parallel and it is determined at which dilutions $50 \%$ of the inoculated cultures are infected. The amount of virus in this dilution is referred to as $\mathrm{ID}_{50}$.

Washed and sterilized germ carriers from cotton No. 11000 (WFK, Krefeld), $10 \times 10$ $\mathrm{mm}$ in size, were moistened with $100 \mu$ of the virus suspension mixed with $40 \%$ fetal calf serum and used without drying. Two times 10 of the contaminated germ carriers were put into one laundry net made of polyester, $10 \times 10 \mathrm{~cm}$ (Pfrommer, Bad Teinach, Germany), each and, together with another laundry net with 10 non-contaminated (sterile) carriers, were transferred to a laundry bag made of polyester, type MNV/GL (Polytex, Bietigheim, Germany). Afterwards, the laundry bag was washed with a contact time of $60 \mathrm{~min} \pm 5 \mathrm{~min}$ and at a temperature of $30^{\circ} \mathrm{C} \pm 3^{\circ} \mathrm{C}$ with ballast laundry ( 1 $\mathrm{kg}$ T-shirts made of a cotton/polyester blend fabric (Trigema, Burladingen, Germany)) in a domestic washing machine (Miele Novotronic W337). Before test washes, a hot 
wash program without product and linen was 3 times performed in the washing machine for cleaning and disinfection matters.

To test the influence of the detergent, two independent tests with a standard powdery laundry detergent (Persil Megaperls ${ }^{\oplus}$, Henkel, Düsseldorf, Germany) were performed. The dosage of detergent was prepared according to manufacturer information (67.5 $\mathrm{g} /$ wash). As a control, a single wash with tap water without detergent additive was performed. After wash cycles, the contaminated and sterile germ carriers were removed from the machine and separately evaluated, both quantitatively and qualitatively. The quantitative evaluation was performed by constant shaking of germ carriers in $900 \mu \mathrm{l}$ DMEM with $5 \%$ fetal calf serum $+100 \mu 10 \times$ PBS (Gibco, Karlsruhe, Germany) with glass beads for $1 \mathrm{~min}$ at $2500 \mathrm{rpm}$. Subsequently, the extracts were diluted and the individual dilution steps were directly given onto a confluent cell culture. The medium was changed every $24 \mathrm{~h}$ and the culture was microscopically controlled daily until the occurrence of a cytopathic effect for a maximum of seven days.

Eluted germ carriers were placed on a confluent cell culture for qualitative analysis and incubated for $24 \mathrm{~h}$ at $36.5^{\circ} \mathrm{C}$ and $7.5 \% \mathrm{CO}_{2}$. Then the medium was changed and the germ carrier was removed. Subsequently, the medium was replaced every $24 \mathrm{~h}$ and the culture was controlled as described above. Similarly, samples of washing liquor were analyzed quantitatively and qualitatively. Therefore, water samples were taken from the washing drum before the first rinsing cycle (time point $\mathrm{T}_{60}$ ) and 2-times $5 \mathrm{ml}$ of this direct sample as well as 2-times $5 \mathrm{ml}$ of sample 1:10 diluted in DMEM were given to a confluent cell culture. The medium was then replaced every $24 \mathrm{~h}$ and the culture was microscopically controlled daily until the occurrence of a cytopathic effect for a maximum of seven days. As a control of initial concentration, an additional water sample was taken already 3 min after the start of program (time point $\mathrm{T}_{0}$ ) and treated similarly.

\section{Results}

\subsection{Specific Detection of Herpes Simplex Virus from Skin Swabs}

For the direct detection of virus by polymerase chain reaction (PCR), swabs were obtained from lesions on the lips of those affected (i.e. swabs of cell-containing material from ruptured or crusted blisters, as well as punctures of blisters). After elution of swabs and isolation of the viral DNA, specific DNA fragments were amplified via PCR and were made visible by gel electrophoresis on a $1 \%$ agarose gel stained with ethidium bromide. To differentiate types of HSV, the $522 \mathrm{bp}$ long amplified sequence of the HSV DNA polymerase was digested with the restriction endonucleases BamHI and Bsh1236I.

In the amplified segment, the polymerase gene is cleaved by BamHI only in the HSV type 2. Therefore, HSV-1 is expected to show a single band of $522 \mathrm{bp}$, whereas HSV-2 is represented by two bands of 292 bp and 230 bp in length. In contrast, Bsh1236I provides a characteristic band pattern by multiple cleavage sites ( 8 or 12 respectively) for both herpes simplex virus types [20]. After digestion and electrophoresis of PCR products, the sampled specimens could thus be identified as HSV-1 isolates by their specific fragment lengths (see Figure 1). 


\subsection{Adhesion of HSV-1 on Textiles}

To answer the question whether herpes simplex virus remains on clothing or textile articles-i.e. outside of the body-for an extended period, small cotton swatches were contaminated with the isolated HSV-1 suspension. After incubation of the textile samples at room temperature for 1 minute, 30 minutes, 1 hour, 2, 4, 6, 8, 24 or 48 hours, the swatches were eluted and the isolated DNA was subjected to PCR analysis. As a control, cotton swatches inoculated with sterile water were eluted similarly.

In addition to this time course series, contaminated cotton swatches were exposed in a domestic laundry process at $40^{\circ} \mathrm{C}$. After the program, the swatches were removed and eluted. Again, the virus DNA remaining on the textile was determined by PCR. So, detectable DNA represents adhering virus particles on the fabric surface.

As shown in Figure 2, herpes simplex virus DNA was detected on all swatches

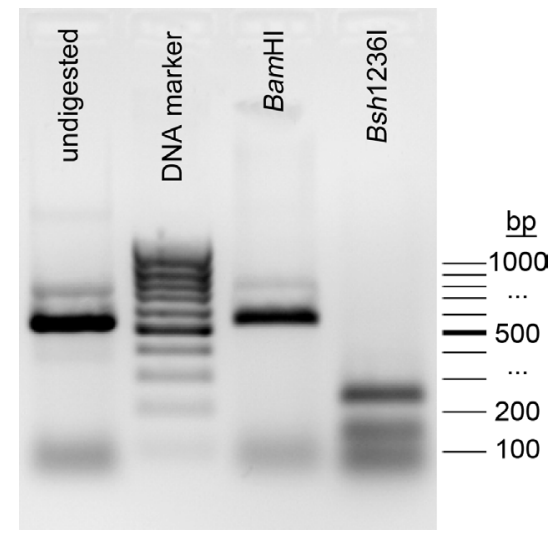

Figure 1. Species identification by restriction digestion of HSV DNA fragments. The amplicon of the isolated virus samples is not digested by BamHI. Only the larger fragments of Bsh1236I digest are visible, but can be identified as characteristic for HSV-1 based on fragment lengths of the DNA marker (100 bp DNA ladder GeneRuler, MBI Fermentas). The largest expected fragments for HSV-1 are $228 \mathrm{bp}, 133 \mathrm{bp}$ and $56 \mathrm{bp}$, for HSV-2 Bsh1236I cleaves fragments with a size of 155 bp, $88 \mathrm{bp}$ and smaller.

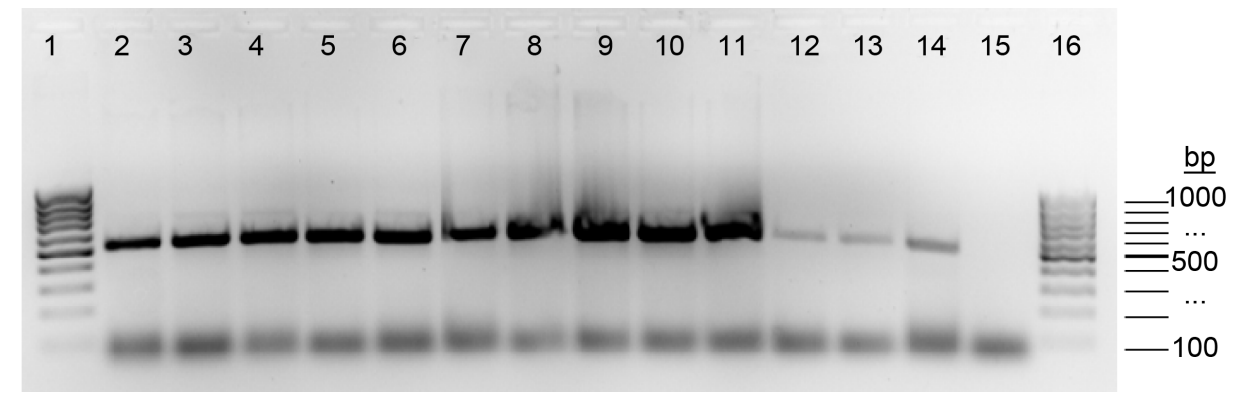

Figure 2. Detection of HSV-1 DNA on contaminated cotton swatches after incubation at room temperature and $40^{\circ} \mathrm{C}$ laundry. 1 and 16: GeneRuler 100 bp DNA Ladder (MBI Fermentas); 2: positive control HSV-1 (suspension); 3 - 11: eluates of textile swatches after incubation at room temperature for a period of 3: 1 minute, 4: 30 minutes, 5: 1 hour, 6: 2 hours, 7: 4 hours, 8: 6 hours, 9: 8 hours, 10: 24 hours, 11: 48 hours; 12 - 14: eluates of textile swatches after washing at $40^{\circ} \mathrm{C} ; 15$ : eluate of cotton swatch moistened with water (negative control). 
contaminated with HSV-1. In both cases, after 48 hours of incubation at room temperature and after washing at $40^{\circ} \mathrm{C}$, detectable amounts of adhering virus DNA were still present on the standard cotton material. Experiments performed with a fabric made of viscose type 401 showed similar results than for cotton (data not shown).

\subsection{Persistence of HSV-1 on Cotton Swatches}

After these first results, the question was still whether the detectable virus DNA resulted from infectious particles and which quantities of particles can survive on fabrics. So, we investigated the stability of infectious particles on cotton swatches after incubation for 30 minutes, 1 hour, 2, 4, 6, 8, 24 and 48 hours at room temperature as well as under cool conditions $\left(2^{\circ} \mathrm{C}-8^{\circ} \mathrm{C}\right)$. Infectious virus particles were notably reduced within the first hour after drying (Table 1). At room temperature, the amount of infectious HSV-1 virus further decreased during the following period and was below the detection limit (here: $1.5 \log _{10} \mathrm{ID}_{50} / \mathrm{ml}$ ) after 48 hours of incubation on cotton. Nevertheless, at lower temperatures the virus survived longer time periods and was still detectable on single swatches after 48 hours. This resulted in an average reduction of virus $\mathrm{TCID}_{50}\left(\mathrm{ID}_{50}\right.$ ) of only $2.5 \log _{10}$ after 48 hours in cool conditions starting with an initial titer of more than $6 \log _{10}$ (see Figure 3).

\subsection{Virus Inactivation by Detergents in Common Household Laundry Processes}

In a typical household washing machine, the effect of detergents in a $30^{\circ} \mathrm{C}$ coloreds program (run time 60 minutes before the pumping and rinsing cycles were started) against HSV-1 on cotton germ carriers was investigated. To demonstrate the effectiveness of the washing detergent, control processes with water only (without detergent) were performed additionally using identical test parameters. In this control process, all germ carriers (20 contaminated and 10 sterile germ carriers) washed without detergent, were virus-positive at the end of the wash cycle. Via contamination of the washing liquor by the 20 germ carriers (corresponds to $2 \mathrm{ml}$ of virus suspension in 7.81 of washing

Table 1. HSV-1 persistence on cotton swatches (Titer and reduction in $\log _{10} \mathrm{ID}_{50} / \mathrm{ml}$ ).

\begin{tabular}{ccccccc}
\hline $\begin{array}{c}\text { Incubation } \\
\text { time }\end{array}$ & $\begin{array}{c}\text { Suspension } \\
\text { control }\end{array}$ & $\begin{array}{c}\text { Virus } \\
\text { control }\end{array}$ & $\begin{array}{c}\text { Swatches at } \\
\mathbf{2}^{\circ} \mathrm{C}-\mathbf{8}^{\circ} \mathrm{C}\end{array}$ & $\begin{array}{c}\text { Reduction at } \\
\mathbf{2}^{\circ} \mathrm{C}-\mathbf{8}^{\circ} \mathrm{C}\end{array}$ & $\begin{array}{c}\text { Swatches at room } \\
\text { temperature }\end{array}$ & $\begin{array}{c}\text { Reduction at room } \\
\text { temperature }\end{array}$ \\
\hline $0 \mathrm{~h}$ & $6.82 \pm 0.18$ & $6.32 \pm 0.14$ & n.t. & n.a. & n.t. & n.a. \\
$0.5 \mathrm{~h}$ & n.t. & n.t. & $6.04 \pm 0.61$ & $0.36 \pm 0.51$ & $5.07 \pm 0.65$ & $1.25 \pm 0.61$ \\
$1 \mathrm{~h}$ & n.t. & n.t. & $5.21 \pm 0.80$ & $1.11 \pm 0.76$ & $4.40 \pm 0.68$ & $1.93 \pm 0.65$ \\
$2 \mathrm{~h}$ & $6.93 \pm 0.20$ & $6.86 \pm 0.69$ & $4.68 \pm 1.31$ & $1.64 \pm 1.28$ & $4.07 \pm 1.02$ & $2.25 \pm 0.98$ \\
$4 \mathrm{~h}$ & $6.89 \pm 0.29$ & $6.64 \pm 0.35$ & $4.93 \pm 1.08$ & $1.39 \pm 1.04$ & $3.39 \pm 0.79$ & $2.93 \pm 0.75$ \\
$6 \mathrm{~h}$ & $7.07 \pm 0.20$ & $6.72 \pm 0.19$ & $4.22 \pm 1.41$ & $2.11 \pm 1.36$ & $\leq 2.18 \pm 0.58$ & $\geq 4.14 \pm 0.54$ \\
$8 \mathrm{~h}$ & $6.93 \pm 0.20$ & $6.54 \pm 0.18$ & $3.86 \pm 1.62$ & $2.46 \pm 1.58$ & $\leq 2.04 \pm 0.39$ & $\geq 4.29 \pm 0.36$ \\
$24 \mathrm{~h}$ & $6.58 \pm 0.30$ & $6.36 \pm 0.21$ & $4.43 \pm 0.51$ & $1.93 \pm 0.51$ & $\leq 1.57 \pm 0.10$ & $\geq 4.79 \pm 0.10$ \\
$48 \mathrm{~h}$ & $6.72 \pm 0.30$ & $6.65 \pm 0.40$ & $3.86 \pm 0.10$ & $2.50 \pm 0.10$ & $\leq 1.50 \pm 0.00$ & $\geq 4.86 \pm 0.00$ \\
\hline
\end{tabular}

n.t. $=$ not tested; n.a. $=$ not applicable. 
liquor), a transfer of virus to the sterile germ carriers was observed (see Figure 4).

At the end of the control wash cycle, a mean titer of 2.9 and $2.5 \mathrm{ID}_{50}$ on the originally contaminated germ carriers and a mean titer of approx. $1.5 \mathrm{ID}_{50}$ on the originally sterile carriers were detected by quantitative analysis of the individual germ carriers (Table 2). The qualitative analysis of washing liquor showed virus-positive results directly after water supply (at time point $\mathrm{T}_{0}$ ) as well as after a processing time of $60 \mathrm{~min}\left(\mathrm{~T}_{60}\right)$ (Table 3).

When using detergent, all germ carriers (20 contaminated and 10 sterile germ carriers) were virus-negative at the end of the washing cycle in the qualitative assessment.

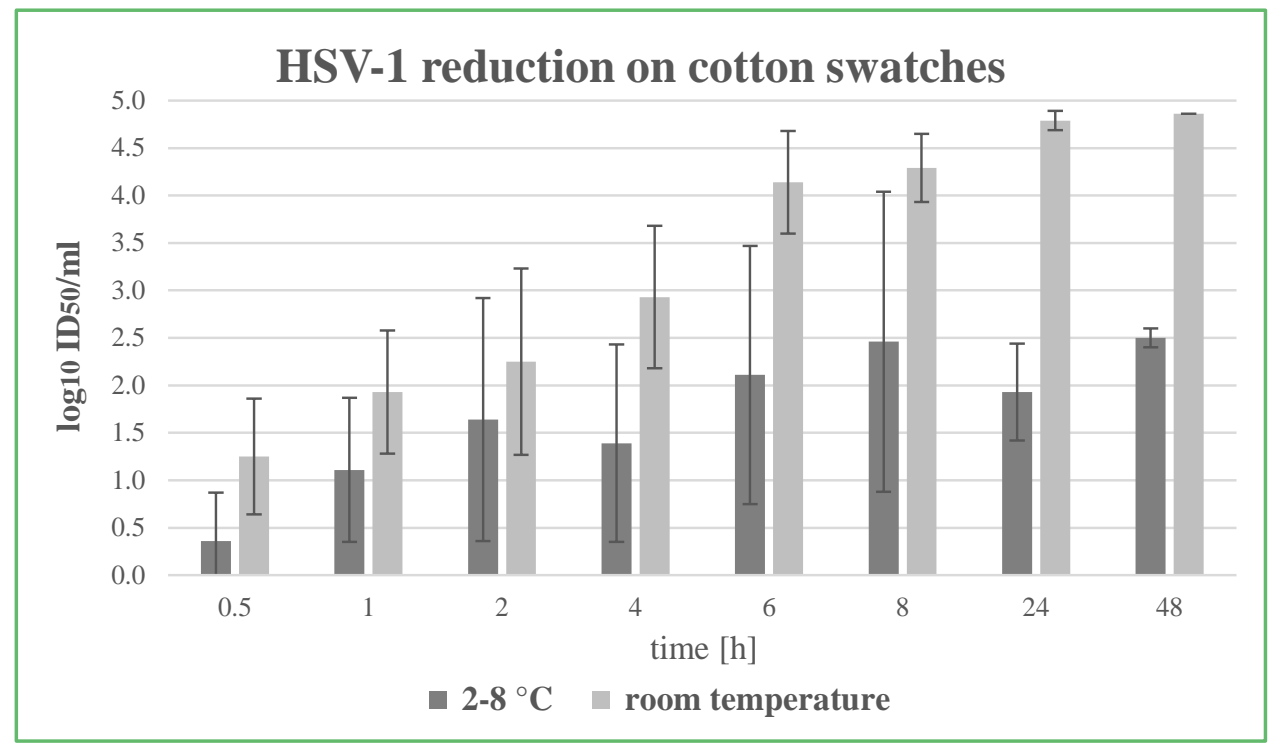

Figure 3. Comparison of HSV-1 reduction on cotton swatches at $2^{\circ} \mathrm{C}-8^{\circ} \mathrm{C}$ and at room temperature.

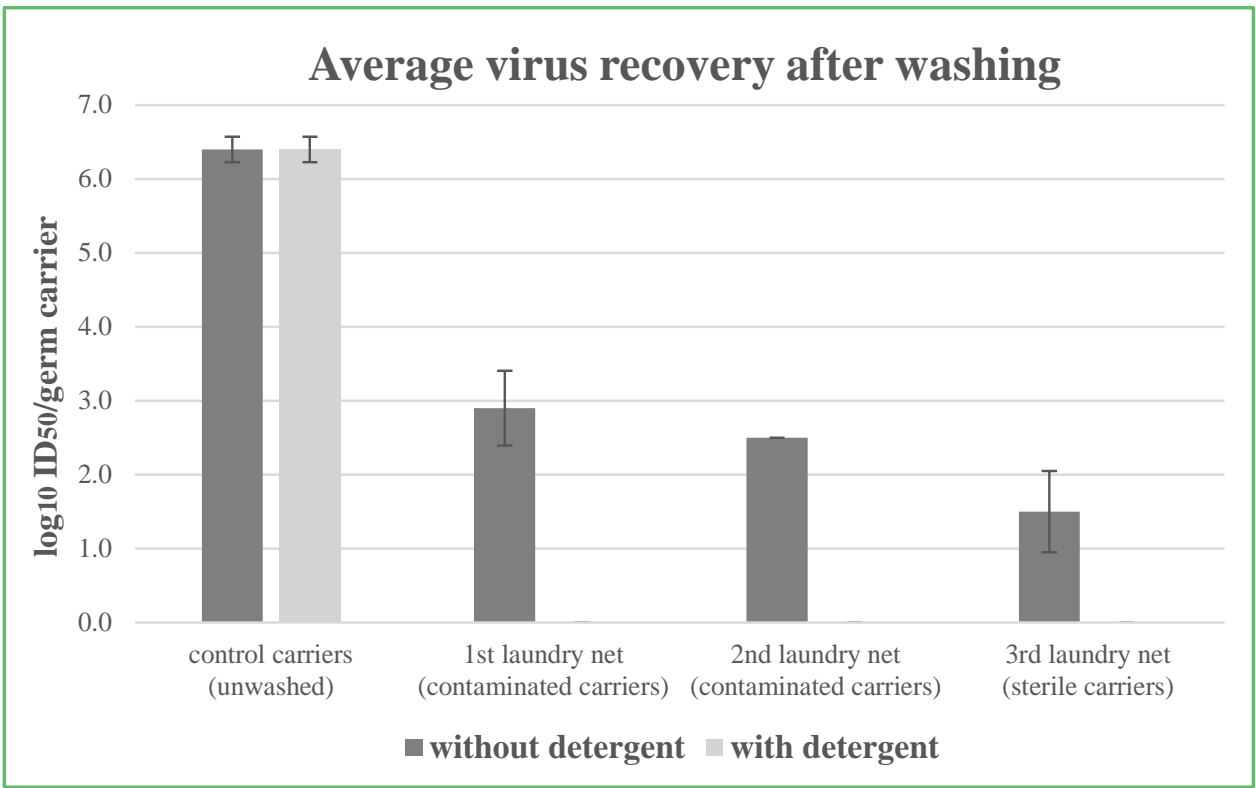

Figure 4. Comparison of average virus recovery from the wash tests without and with detergent. 
Table 2. Virus recovery from a wash test without detergent, parallel processing in the same wash cycle.

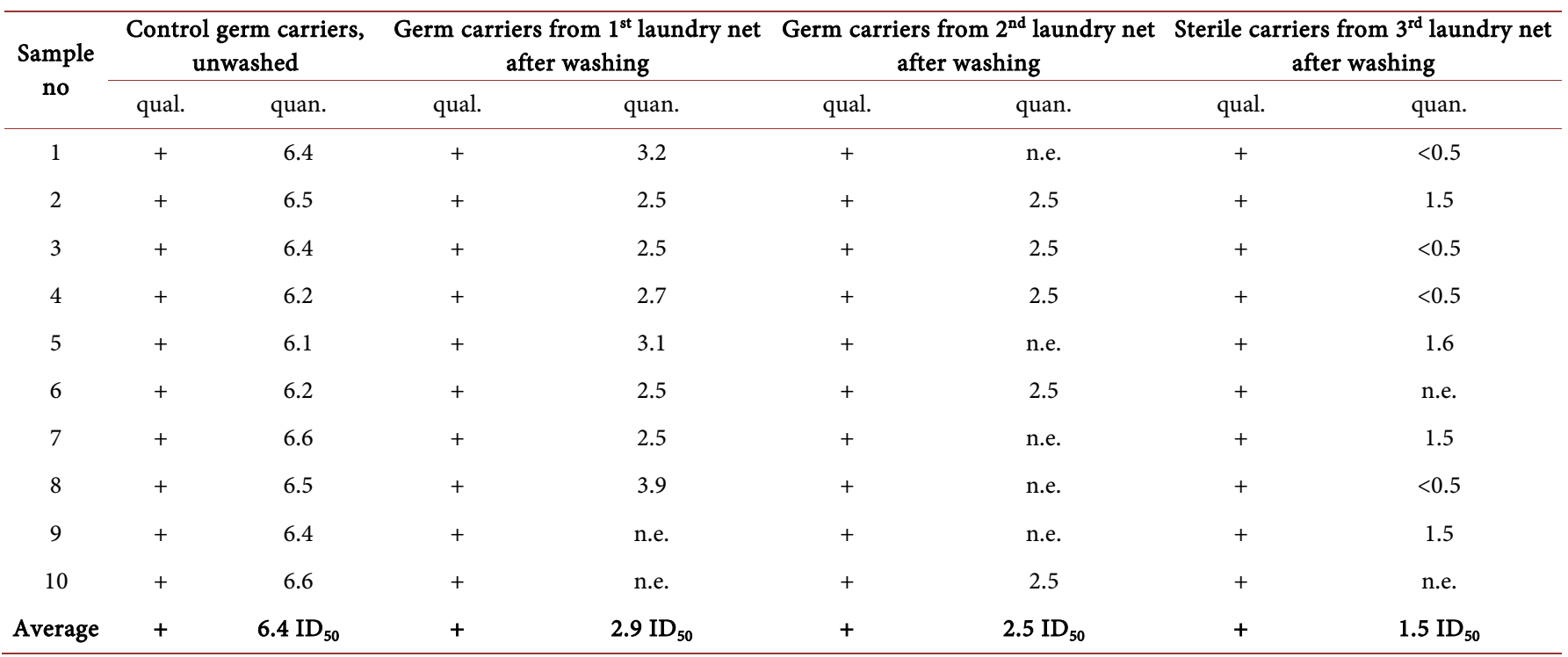

qual. $=$ qualitative analysis; quan. $=$ quantitative analysis; $+=$ virus-positive; n.e. $=$ not evaluable .

Table 3. Analysis of washing liquor from the wash test without detergent.

\begin{tabular}{ccccccc}
\hline \multirow{2}{*}{ Sample no } & \multicolumn{3}{c}{ Sampling at start of program $\left(\mathrm{T}_{0}\right)$} & \multicolumn{3}{c}{ Sampling at end of program $\left(\mathrm{T}_{60}\right)$} \\
\cline { 2 - 6 } & direct (qual.) & $1: 10$ diluted (qual.) & quan. $\left(\mathrm{ID}_{50}\right)$ & direct (qual.) & $1: 10$ diluted (qual.) & quan. (ID $\left._{50}\right)$ \\
\hline 1 & toxic & + & n.e. & + & + & +1.5 \\
2 & + & + & $\geq 1.5$ & + & + & +1.5 \\
\hline
\end{tabular}

qual. $=$ qualitative analysis; quan. $=$ quantitative analysis; $+=$ virus-positive; n.e. $=$ not evaluable. $\mathrm{An}_{\mathrm{ID}} \mathrm{D}_{50}$ of $\geq 1.5$ indicates that the first dilution of quantitative analysis was contaminated with bacteria.

Also in the quantitative analysis of the individual germ carriers, no infectious virus could be detected $\left(<0.5 \mathrm{ID}_{50}\right)$ (Table 4$)$. A second, independent series of experiments led to the same result (data not shown). The washing liquor was virus-negative in the qualitative analysis of water samples at time points $\mathrm{T}_{0}$ and $\mathrm{T}_{60}$ (Table 5).

\section{Discussion}

In the present study, we qualitatively investigated the adhesion of herpes viruses on textiles using virus isolates from herpes blisters and the polymerase chain reaction. Additionally, by using a laboratory virus strain, we examined the persistence of infectious particles on these textiles quantitatively. Furthermore, we wanted to clarify whether specific household laundry processes are capable of solving the problem of virus-contaminated textiles, to prevent possible herpes virus infections in the population with common methods.

The polymerase chain reaction (PCR) is routinely used for years as a diagnostic tool for the direct identification of pathogens [22]. Therefore, the viral nucleic acid is enzymatically amplified from patient swabs, fluid samples etc. The method advantageously allows the specific detection of viral DNA even from small amounts of initial sample. 
Table 4. Virus recovery from a wash test with detergent, parallel processing in the same wash cycle.

\begin{tabular}{|c|c|c|c|c|c|c|c|c|}
\hline \multirow{2}{*}{$\begin{array}{l}\text { Sample } \\
\text { no }\end{array}$} & \multicolumn{2}{|c|}{$\begin{array}{l}\text { Control germ carriers, } \\
\text { unwashed }\end{array}$} & \multicolumn{2}{|c|}{$\begin{array}{c}\text { Germ carriers from } 1^{\text {st }} \text { laundry net } \\
\text { after washing }\end{array}$} & \multicolumn{2}{|c|}{$\begin{array}{c}\text { Germ carriers from } 2^{\text {nd }} \text { laundry net } \\
\text { after washing }\end{array}$} & \multicolumn{2}{|c|}{$\begin{array}{c}\text { Sterile carriers from } 3^{\text {rd }} \text { laundry net } \\
\text { after washing }\end{array}$} \\
\hline & qual. & quan. & qual. & quan. & qual. & quan. & qual. & quan. \\
\hline 2 & + & 6.5 & - & $<0.5$ & - & $<0.5$ & - & $<0.5$ \\
\hline 3 & + & 6.4 & - & $<0.5$ & - & $<0.5$ & - & $<0.5$ \\
\hline 5 & + & 6.1 & - & $<0.5$ & - & $<0.5$ & - & $<0.5$ \\
\hline 6 & + & 6.2 & - & $<0.5$ & - & $<0.5$ & - & $<0.5$ \\
\hline 7 & + & 6.6 & - & $<0.5$ & - & $<0.5$ & - & $<0.5$ \\
\hline 8 & + & 6.5 & - & $<0.5$ & - & $<0.5$ & - & $<0.5$ \\
\hline Average & + & $6.4 \mathrm{ID}_{50}$ & - & $<0.5 \mathrm{ID}_{50}$ & - & $<0.5 \mathrm{ID}_{50}$ & - & $<0.5 \mathrm{ID}_{50}$ \\
\hline
\end{tabular}

qual. = qualitative analysis; quan. = quantitative analysis; + = virus-positive; - = virus-negative.

Table 5. Analysis of washing liquor from the wash test with detergent.

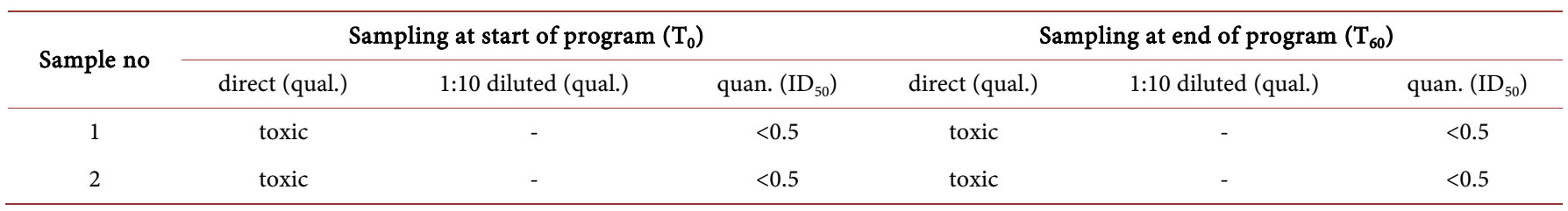

qual. = qualitative analysis; quan. = quantitative analysis; + = virus-positive; n.e. = not evaluable.

Therefore, we were able to identify herpes virus type 1 from skin lesions from affected patients via the DNA. With HSV-1 suspensions obtained from lesions, cotton swatches were contaminated and stored for up to 2 days. In contrast to a study of Turner et al. (1982), who described that herpes virus survived no longer than two to four hours outside the oral cavity on plastic and textile surfaces, our studies showed a strong persistence of HSV-1 DNA on textile swatches. Also after a standard household laundering process at $40^{\circ} \mathrm{C}$, detectable amounts of virus DNA were present, representing adhering virus particles. The disadvantage of the very sensitive and specific PCR method is that also inactivated virus material will be detected. For a risk assessment of infection or re-infection with herpes virus, we therefore had to answer the question, whether infectious particles persist under the above conditions besides the detection of viral genetic material. Thus, we quantitatively investigated the persistence of HSV-1 on textiles using virus titration of the laboratory strain hv342. These further results somehow generally confirmed the findings of Turner et al. (1982) and showed a significant decrease in infectivity of virus particles within 4 to 6 hours at room temperature. Nevertheless, notable titers of infectious particles could be shown after incubation at cool conditions $\left(2^{\circ} \mathrm{C}\right.$ $8^{\circ} \mathrm{C}$ ), even after 48 hours. This result reveals new insight in the persistence of HSV-1 and might play a role in winter, when herpes blisters are commonly present in affected 
persons and a transmission route via textiles can be relevant. Despite only few data on the survival of HSV on inanimate surfaces, Kramer et al. (2006) earlier concluded that HSV can persist longer in low humidity and at low temperature.

Furthermore, we particularly wanted to know if infectious viruses can be found on textiles after a common household laundry process. For this reason, we developed textile germ carriers, charged with the HSV-1 laboratory strain hv342, and examined the infectivity of virus after washing. Since it is known that virus transfer from viruscontaminated textiles to other textiles is possible [23] [24], the viral load of the wash liquor and of initially sterile textile samples, washed in the same machine, were determined additionally.

The initially applied amount of virus was quantitatively recovered from unwashed control germ carriers. For the methodology and preparation used in this work it can be therefore concluded that the recovery rate of inserted virus is apparently high enough to subsequently record a reduction in viral load. The experiments were carried out in several parallels to ensure a higher confidence level and to compensate possible failures due to bacterial contamination of cell culture.

In a wash test without detergent, the reliable detection of virus-positive samples indicates an insufficient inactivation of virus during the laundry process. This could be stated although individual samples were not evaluable and the interpretation of results of water samples is difficult because of toxic effects of the wash liquor to cell cultures. These are probably due to an initial lack of mixing in the drum. However, the observed transmission of virus to previously not contaminated textiles in the control wash cycle can be explained by virus contamination of the wash liquor originating from introduced germ carriers.

In contrast, herpes virus has been completely inactivated by a common household laundry process at $30^{\circ} \mathrm{C}$ using a detergent. This is apparent not only in the complete reduction on the contaminated germ carriers, but also by the fact that neither in the wash liquor nor on sterile germ carriers infectious virus particles could be detected. With regard to an infection risk, this result has to be considered in correlation to the required infectious dose of the pathogen. This is currently not known for HSV-1 [12]. However, one can assume that a reduction of the viral titer below a threshold that triggers a cytopathic effect in cell culture, in principle would exclude an infection risk in vivo, too. Against this background, it must be considered that the proof of the effectiveness of household laundry processes against viruses so far could be mainly provided with the help of in vitro methods, e.g. in accordance with guidelines of the RKI and DVV [21]. In the last years, methods have been published evaluating the virus-inactivating efficacy of laundry processes under realistic conditions [24] [25] [26]. In this study, a practical approach for evaluating the effectiveness of common household laundry processes against herpes viruses is provided for the first time.

In direct comparison to the studies of Heinzel et al. (2010), where a complete inactivation of polio virus in the tested washing procedures was observed, enveloped viruses seem to behave similarly in principle. Interestingly, our results showed that herpes vi- 
ruses are apparently not inactivated solely by water and the laundry process, which is in some contradiction to the results of Turner et al. (1982), who found a survival rate of only two to four hours in the environment. If a low drying tolerance of herpes virus should play a crucial role here, this might, conversely, result in a prolonged virus survival of herpes viruses on textiles in a laundry process without adequate use of detergent. Given that in practice there are many different washing machines, detergents and laundry processes used in households, standard recommendations for the inactivation of pathogens, like the use of bleaching agents or temperatures $\geq 60^{\circ} \mathrm{C}$, should be noted. Nevertheless, one can estimate similar efficacy to this presented in our results with other standard detergents, because surfactants damage the lipid envelope of herpes virus and thereby will lead to an inactivation of particles.

Overall, our results show that domestic laundry was able to inactivate virus particles given that detergents were adequately used. With standard household laundry processes, family- and user-friendly procedures have been established in Europe to prevent infections circulating in the household and the community as propagated by experts [11].

\section{References}

[1] Hellenbrand, W., Thierfelder, W., et al. (2005) Seroprevalence of Herpes Simplex Virus Type 1 (HSV-1) and Type 2 (HSV-2) in Former East and West Germany, 1997-1998. European Journal of Clinical Microbiology \& Infectious Diseases, 24, 131-135. https://doi.org/10.1007/s10096-005-1286-X

[2] Sauerbrei, A., Schmitt, S., et al. (2011) Seroprevalence of Herpes Simplex Virus Type 1 and Type 2 in Thuringia, Germany, 1999 to 2006. Eurosurveillance, 16, No. 44.

[3] Marques, N.M., Margalho, R., et al. (2011) Seroepidemiological Survey of Transmissible Infectious Diseases in a Portuguese Prison Establishment. Brazilian Journal of Infectious Diseases, 15, 272-275. https://doi.org/10.1016/S1413-8670(11)70188-X

[4] Kucera, P., Gerber, S., et al. (2012) Seroepidemiology of Herpes Simplex Virus Type 1 and 2 in Pregnant Women in Switzerland: An Obstetric Clinic Based Study. European Journal of Obstetrics \& Gynecology and Reproductive Biology, 160, 13-17. https://doi.org/10.1016/j.ejogrb.2011.09.030

[5] Doerr, H.W. and Rabenau, H. (1996) [Dermatotropic Herpes Viruses: Infection Biology, Epidemiology and Diagnostics] Dermatotrope Herpesviren: Infektionsbiologie, Epidemiologie und Diagnostik. Chemotherapie Journal, 5, 1-11.

[6] Chenot, J.F., Rabenau, H.F., et al. (1999) Virologie, Epidemiologie und Diagnostik des Herpes genitalis. Deutsche Medizinische Wochenschrift, 124, 158-162.

https://doi.org/10.1055/s-2007-1024268

[7] Buxbaum, S., Geers, M., et al. (2003) Epidemiology of Herpes Simplex Virus Types 1 and 2 in Germany: What Has Changed? Medical Microbiology and Immunology, 192, 177-181. https://doi.org/10.1007/s00430-003-0183-0

[8] Wald, A., Zeh, J., et al. (2002) Genital Shedding of Herpes Simplex Virus among Men. The Journal of Infectious Diseases, 186, S34-S39. https://doi.org/10.1086/342969

[9] Kaufman, H. E., Azcuy, A.M., et al. (2005) HSV-1 DNA in Tears and Saliva of Normal Adults. Investigative Ophthalmology \& Visual Science, 46, 241-247. https://doi.org/10.1167/iovs.04-0614 
[10] Schulte, J.M., Bellamy, A.R., et al. (2014) HSV-1 and HSV-2 Seroprevalence in the United States among Asymptomatic Women Unaware of any Herpes Simplex Virus Infection (Herpevac Trial for Women). Southern Medical Journal, 107, 79-84. https://doi.org/10.1097/SMJ.0000000000000062

[11] Bloomfield, S.F., Exner, M., et al. (2008) [Prevention of Infection through Hygiene in the Home and Community. The Need for a Family-Centred Approach]. Bundesgesundheitsblatt Gesundheitsforschung Gesundheitsschutz, 51, 1258-1263. https://doi.org/10.1007/s00103-008-0695-2

[12] Sacks, S.L., Griffiths, P.D., et al. (2004) HSV Shedding. Antiviral Research, 63, 19-26. https://doi.org/10.1016/j.antiviral.2004.06.004

[13] Bloomfield, S., Exner, M., et al. (2008) Prevention of the Spread of Infection-The Need for a Family-Centred Approach to Hygiene Promotion. Eurosurveillance, 13, 1-4.

[14] Gerhardts, A., Mucha, H., et al. (2012) [On the Role of Textile Surfaces in the Chain of Infection]. Hygiene \& Medizin, 37, 400-403.

[15] Mahl, M.C. and Sadler, C. (1975) Virus Survival on Inanimate Surfaces. Canadian Journal of Microbiology, 21, 819-823. https://doi.org/10.1139/m75-121

[16] Nerurkar, L.S., West, F., et al. (1983) Survival of Herpes Simplex Virus in Water Specimens Collected from Hot Tubs in Spa Facilities and on Plastic Surfaces. JAMA, 250, 3081-3083. https://doi.org/10.1001/jama.1983.03340220049032

[17] Dixon, G.J., Sidwell, R.W., et al. (1966) Quantitative Studies on Fabrics as Disseminators of Viruses. II. Persistence of Poliomyelitis Virus on Cotton and Wool Fabrics. Appl Microbiol, 14, 183-188.

[18] Sidwell, R.W., Dixon, G.J., et al. (1966) Quantitative Studies on Fabrics as Disseminators of Viruses. I. Persistence of Vaccinia Virus on Cotton and Wool Fabrics. Journal of Applied Microbiology, 14, 55-59.

[19] Sidwell, R.W., Dixon, G.J., et al. (1967) Quantitative Studies on Fabrics as Disseminators of Viruses. III. Persistence of Vaccinia Virus on Fabrics Impregnated with a Virucidal Agent. Journal of Applied Microbiology, 15, 921-927.

[20] Johnson, G., Nelson, S., et al. (2000) Comprehensive PCR-Based Assay for Detection and Species Identification of Human Herpesviruses. Journal of Clinical Microbiology, 38, 32743279.

[21] Rabenau, H.F., Schwebke, I., Blumel, J., Eggers, M., Glebe, D., Rapp, I., Sauerbrei, A., Steinmann, E., Steinmann, J., Willkommen, H. and Wutzler, P. (2015) [Guideline of the German Association for the Control of Viral Diseases (DVV) eV and the Robert Koch Institute (RKI) for Testing Chemical Disinfectants for Effectiveness against Viruses in Human Medicine. Version of 1 December, 2014]. Bundesgesundheitsblatt Gesundheitsforschung Gesundheitsschutz, 58, 493-504. https://doi.org/10.1007/s00103-015-2131-8

[22] Enders, G. (1992) [Virus Infections] Virusinfektionen. In: Thomas, L., Ed., [Lab and Diagnosis] Labor und Diagnose, Med. Verlagsgesellschaft, Marburg, 1545-1630.

[23] Sidwell, R.W., Dixon, G.J., et al. (1970) Quantitative Studies on Fabrics as Disseminators of Viruses. IV. Virus Transmission by Dry Contact of Fabrics. Journal of Applied Microbiology, 19, 950-954.

[24] Gerhardts, A., Wilderer, C., et al. (2009) [Testing of Disinfecting Laundry Processes against Viruses via Application of Bioindicators and the Surrogate Virus MS2, Part 1: Low-Temperature Laundry]. Hygiene \& Medizin, 34, 272-281.

[25] Heinzel, M., Kyas, A., et al. (2010) Evaluation of the Virucidal Performance of Domestic Laundry Procedures. International Journal of Hygiene and Environmental Health, 213, 334- 


\section{7. https://doi.org/10.1016/j.ijheh.2010.06.003}

[26] Gerhardts, A., Mucha, H., et al. (2012) Testing Linen Disinfection Procedures in Practice with Phage-Charged Bioindicators. International Journal of Health Care Quality Assurance, 25, 519-531. https://doi.org/10.1108/09526861211246476

Submit or recommend next manuscript to SCIRP and we will provide best service for you:

Accepting pre-submission inquiries through Email, Facebook, LinkedIn, Twitter, etc. A wide selection of journals (inclusive of 9 subjects, more than 200 journals)

Providing 24-hour high-quality service

User-friendly online submission system

Fair and swift peer-review system

Efficient typesetting and proofreading procedure

Display of the result of downloads and visits, as well as the number of cited articles Maximum dissemination of your research work

Submit your manuscript at: http://papersubmission.scirp.org/

Or contact jbm@scirp.org 